\title{
Microwear analysis of small recycled flakes and recycling products from the Ein-Zippori site, Lower Galilee, Israel
}

\author{
Richard W. Yerkes ${ }^{1}$, Yoni Parush ${ }^{2}$, Avi Gopher ${ }^{2}$, Ran Barkai ${ }^{2}$ \\ 1. Department of Anthropology, Ohio State University. 4034 Smith Lab., 174 W. 18th Ave., Columbus, OH \\ 43210-1106, U.S.A. Email: yerkes.1@osu.edu \\ 2. Tel Aviv University, Dept. Archaeology and Ancient Near Eastern Cultures, and Sonia and Marco Nadler \\ Institute of Archaeology, Tel-Aviv University, Tel-Aviv 69978, Israel. Email: Parush: yoniparush@ gmail.com; \\ Gopher: agopher@post.tau.ac.il; Barkai: barkaran@post.tau.ac.il
}

\begin{abstract}
:
A microwear analysis of recycled lithic artefacts from late Pottery Neolithic Wadi Rabah and Early Bronze Age layers at Ein-Zippori, Israel included cores-on-flakes (COFs) which are discarded blanks made into cores, and the flakes detached from them. COFs may have microwear traces that formed before they were recycled. The focus here is on how blanks removed from recycled COFs were used. Discarded flakes were not used as cores to produce small blanks at Ein-Zippori because lithic raw material was scarce, but were COFs recycled so that small tools could be produced for specific tasks? Visible wear traces were present on 19 of 44 blanks produced from COFs. Microwear traces were similar to use wear Lemorini et al. (2015) observed on much older Lower Paleolithic recycled flakes from Qesem Cave, Israel. Most flakes struck from COFs had been used to cut and scrape meat and fresh hide $(42 \%, \mathrm{n}=8)$, but four were used to work wood $(21 \%)$ and four others were used to cut, scrape, or whittle bone and wood (21\%), and two were used for butchering and wood working (11\%). One flake only had generic weak microwear traces $(5 \%)$. These were expedient flake tools, made and used in an ad hoc fashion. Specific blanks do not seem to have been used for distinct tasks.
\end{abstract}

Keywords: recycled artefacts; microwear analysis; late Pottery Neolithic; Wadi Rabah; Early Bronze Age

\section{Introduction}

Results of a microwear analysis of a sample of 69 recycled flaked stone artifacts from the large late prehistoric Ein-Zippori site located $2 \mathrm{~km}$ west of Nazareth in the Lower Galilee, Israel are presented. Recycling is modifying previously used artefacts so they can be used in other activities (Vaquero et al. 2012). Lithic artefact recycling is not the same as resharpening, since recycled tools are not repaired so they can continue to be used for the same tasks. Recycling previously discarded artefacts has been practiced since ancient times. Sometimes utilized tools are curated or cached for future use at sites where they can be recycled. In North America, both highly mobile foragers and less mobile logistical hunterISSN: 2055-0472. URL: http://journals.ed.ac.uk/lithicstudies/ 
gatherers often cached stone tools that they manufactured elsewhere at sites where lithic raw material was not abundant (Yerkes and Koldehoff 2018:80). Many studies of recycled lithic artefacts in the Old World focused on the activities of mobile foragers during the Paleolithic at locations were lithic raw material was scarce, but also in places where flint was abundant (see Parush et al. 2018 and references therein). The temporal context of this functional study of flake blanks produced from recycled flakes used as cores is much later than the Paleolithic. It is during the Late Pottery Neolithic period and Early Bronze Age, when farmers in the southern Levant made and used new (and different) types of flint tools. Ein-Zippori was an example of expedient recycling by settled agriculturalists at a location where lithic raw material was abundant (Parush et al. 2018). Small flake blanks were produced quickly for tasks that needed to be completed immediately. The goals of this microwear study are to determine the function of these small flakes, identify the tasks they were used for, and learn if different types of blanks were used for specific tasks.

The microwear sample included discarded recycled flakes called cores-on-flakes (COFs) and the different types of blanks that were struck from them. Since COFs may have microwear traces on their edges that formed when they were used before they were recycled, those prior activities are not the focus of this study. In this study, the function of COFs was to serve as cores for the production of new blanks. Functions of the small blanks were determined by examining microscopic wear traces on their edges. The microwear analysis was conducted in 2014 and 2015 at Tel Aviv University and at Ohio State University.

Excavations at Ein-Zippori were conducted by the Israeli Antiquities Authority between 2011 and 2013. The 14 excavation areas (A - N) at the site contained archaeological layers identified as Pre-Pottery Neolithic (PPNB and PPNC), Late Pottery Neolithic (Wadi Rabah, WR), and Early Bronze Age (EBA) Ib and II. Other sporadic finds were collected from top soil layers and were dated to the Roman, Byzantine and Crusader periods (Agam et al. 2016). Recycled artefacts from the two main occupations, Late Pottery Neolithic WR and EBA Ib and II were examined (see Parush et al. 2018 for details about site location and excavated areas). Most recycled artefacts came from WR layers, but artefacts from EBA contexts at the site are included in the microwear sample, which is treated as one assemblage. More detailed contextual analyses can be conducted in the future. A single blank from a PPNB layer was also examined. It is listed at the bottom of Table 1, and had no visible microwear. Artefacts in the microwear sample came from six of the excavated areas: B, C, E, K2, L, and N2 (Table 1, Figure 1). Most were from Areas B, C, and E at Ein-Zippori.

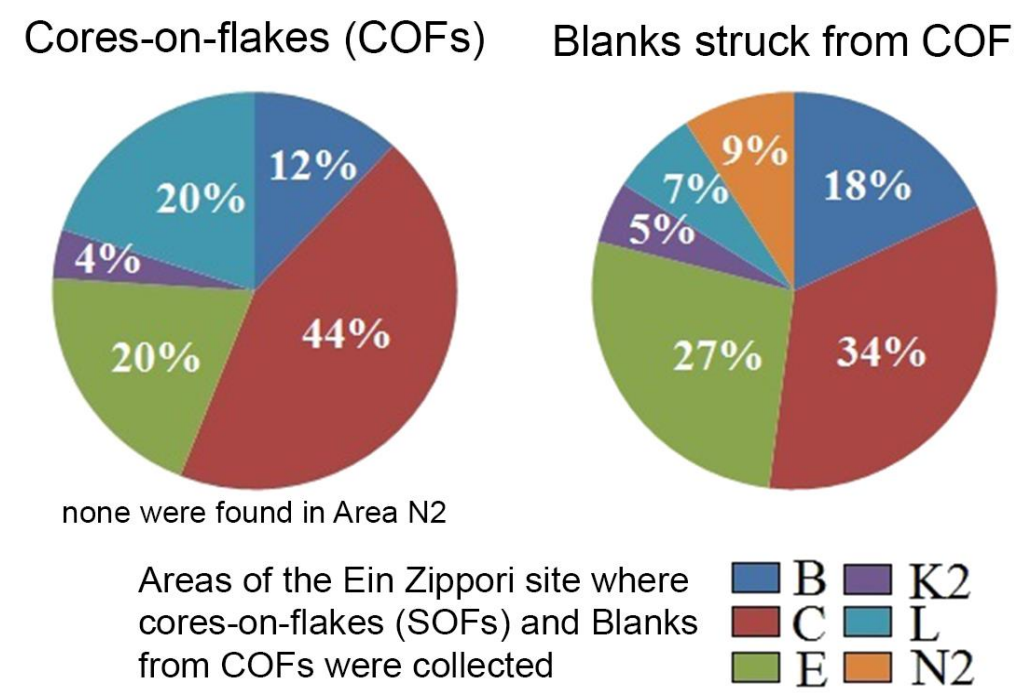

Figure 1. Percentage of the 25 cores-on-flakes (left) and the 44 blanks struck from COFs (right) in the microwear sample collected from six areas of the the Ein-Zippori site. There were no COFs from Area N2. 
Table 1. Ein-Zippori Recycled Artefacts Microwear Results. See Figures 5-8 for images of the artefacts and wear traces. Abbreviations: NA = not available; (?) = possible.

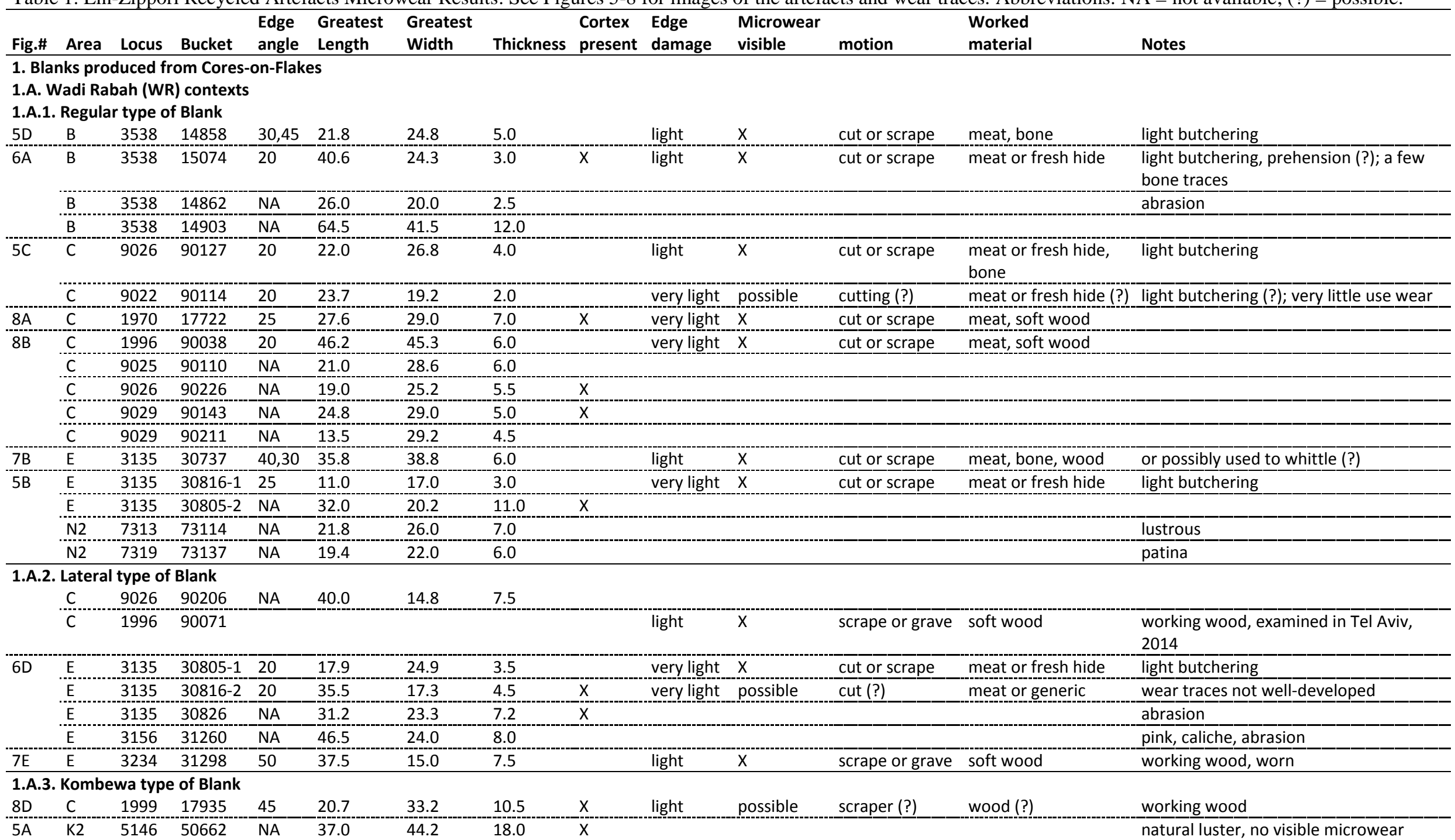




\begin{tabular}{|c|c|c|c|c|c|c|c|c|c|c|c|c|c|}
\hline Fig.\# & Area & Locus & Bucket & $\begin{array}{l}\text { Edge } \\
\text { angle }\end{array}$ & $\begin{array}{l}\text { Greatest } \\
\text { Length }\end{array}$ & $\begin{array}{l}\text { Greatest } \\
\text { Width }\end{array}$ & Thickness & $\begin{array}{l}\text { Cortex } \\
\text { present }\end{array}$ & $\begin{array}{l}\text { Edge } \\
\text { damage }\end{array}$ & $\begin{array}{l}\text { Microwear } \\
\text { visible }\end{array}$ & motion & $\begin{array}{l}\text { Worked } \\
\text { material }\end{array}$ & Notes \\
\hline \multicolumn{14}{|c|}{ 1.A.4. Double-bulb Lateral type of Blank } \\
\hline \multirow[t]{2}{*}{ 7C } & $\mathrm{C}$ & 9022 & 90134 & 45 & 47.0 & 17.0 & 10.5 & $x$ & light & $x$ & cut or scrape & meat, bone, wood & or possibly used to whittle (?) \\
\hline & $\mathrm{E}$ & 3234 & 31322 & NA & 67.0 & 22.3 & 10.0 & & & & & & irregular shape \\
\hline 7D & N2 & 7319 & 73141 & 30 & 32.4 & 13.3 & 6.0 & & light & $\mathrm{X}$ & cut or scrape & meat, bone, wood & or possibly used to whittle (?) \\
\hline \multicolumn{14}{|c|}{ 1.A.5. Tabun Snap type of Blank } \\
\hline $6 C$ & $\mathrm{C}$ & 1996 & 90045 & 25 & 41.0 & 15.3 & 4.0 & & very light & $x$ & cut or scrape & meat or fresh hide & light butchering, prehension (?) \\
\hline \multirow[t]{5}{*}{$8 C$} & $\mathrm{C}$ & 1996 & 90071 & 45 & 44.0 & 23.5 & 10.5 & $x$ & light & possible & scraper (?) & wood (?) & working wood \\
\hline & $\mathrm{C}$ & 9022 & 90138 & NA & 26.4 & 16.0 & 7.5 & $\mathrm{x}$ & & & & & \\
\hline & $\mathrm{E}$ & 3158 & 30866 & NA & 36.0 & 17.4 & 7.7 & $\mathrm{X}$ & & & & & \\
\hline & $E$ & 3234 & 31318 & NA & 44.0 & 19.6 & 16.0 & $x$ & & & & & wedge-shaped, abrasion \\
\hline & $\mathrm{E}$ & 3247 & 31393 & NA & 56.5 & 25.3 & 13.5 & & & & & & wedge-shaped, abrasion, patina \\
\hline \multicolumn{14}{|c|}{ 1.A.6. varia } \\
\hline & $\mathrm{K} 2$ & 5101 & 50356 & NA & 26.0 & 28.5 & 10.0 & & & & & & caliche, abrasion \\
\hline \multicolumn{14}{|c|}{ 1.B. Early Bronze Age (EBA) contexts } \\
\hline \multicolumn{14}{|c|}{ 1.B.1. Regular type of Blank } \\
\hline & B & 1321 & 13241 & NA & 27.2 & 23.4 & 4.5 & & & & & & caliche on dorsal face \\
\hline \multirow[t]{2}{*}{$7 \mathrm{~A}$} & $\mathrm{~B}$ & 1501 & 13923 & 40,20 & 34.6 & 22.8 & 7.5 & & light & $x$ & cut or scrape & meat, bone, wood & or possibly to whittle (?) \\
\hline & L & 6081 & 60348 & NA & 22.6 & 33.0 & 6.5 & & & & & & looks like a scraper \\
\hline \multicolumn{14}{|c|}{ 1.B.2. Lateral type of Blank } \\
\hline & $\mathrm{L}$ & 6065 & 60346 & NA & 26.4 & 9.2 & 9.0 & $x$ & & & & & triangular shaped \\
\hline \multicolumn{14}{|c|}{ 1.B.3. Kombewa type of Blank } \\
\hline \multirow[t]{2}{*}{$6 B$} & $\mathrm{~B}$ & 1321 & 13266 & 45 & 19.8 & 23.9 & 6.0 & & light & $x$ & cut or scrape & meat or fresh hide & light butchering, caliche on dorsal face \\
\hline & $\mathrm{B}$ & 1562 & 14380 & NA & 19.5 & 19.1 & 3.7 & & & & & & abrasion \\
\hline \multicolumn{14}{|c|}{ 1.B.4. Double-bulb Lateral type of Blank } \\
\hline & $\mathrm{L}$ & 6078 & 60236 & NA & 40.1 & 13.0 & 7.0 & $x$ & & & & & triangular shaped \\
\hline
\end{tabular}




\begin{tabular}{|c|c|c|c|c|c|c|c|c|c|c|c|c|c|}
\hline Fig.\# & Area & Locus & Bucket & $\begin{array}{l}\text { Edge } \\
\text { angle }\end{array}$ & $\begin{array}{l}\text { Greatest } \\
\text { Length }\end{array}$ & $\begin{array}{l}\text { Greatest } \\
\text { Width }\end{array}$ & Thickness & $\begin{array}{l}\text { Cortex } \\
\text { present }\end{array}$ & $\begin{array}{l}\text { Edge } \\
\text { damage }\end{array}$ & $\begin{array}{l}\text { Microwear } \\
\text { visible }\end{array}$ & motion & $\begin{array}{l}\text { Worked } \\
\text { material }\end{array}$ & Notes \\
\hline \multicolumn{14}{|c|}{ 2. Cores-on-flakes (COFs) } \\
\hline \multicolumn{14}{|c|}{ 2.A. Wadi Rabah (WR) contexts } \\
\hline \multicolumn{14}{|c|}{ 2.A.1. Ventral type of COF } \\
\hline \multirow[t]{2}{*}{$3 \mathrm{~A}$} & B & 3538 & $14858-1$ & 60 & 39.5 & 39.0 & 7.5 & $x$ & very light & possible & scrape (?) & fresh hide (?) & lateral snap, very little use wear \\
\hline & $\mathrm{B}$ & 3538 & $14858-2$ & & & & & $\mathrm{x}$ & light & $x$ & cut or scrape & meat or fresh hide & $\begin{array}{l}\text { prehension (?); A few bone traces, } \\
\text { examined in Tel Aviv }\end{array}$ \\
\hline $3 B$ & $B$ & 3538 & 14903 & 70 & 61.0 & 38.0 & 22.5 & $\mathrm{x}$ & very light & possible & scraper (?) & hide, stone & patina, very little use wear \\
\hline \multirow[t]{17}{*}{$3 C$} & C & 9025 & 90157 & NA & 60.0 & 45.5 & 20.0 & $\mathrm{X}$ & & & & & "flake-core" \\
\hline & C & 1970 & 17792 & NA & 34.7 & 27.0 & 9.5 & & & & & & lustrous \\
\hline & C & 1979 & 17833 & NA & 50.0 & 35.8 & 10.7 & & & & & & abrasion \\
\hline & 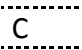 & 1996 & 17916 & NA & 43.5 & 33.5 & 13.5 & $x$ & & & & & coarse-grained flint \\
\hline & C & 1996 & 17995 & NA & 53.0 & 40.0 & 20.5 & $\mathrm{X}$ & & & & & patina, battered \\
\hline & C & 1996 & 90045 & NA & 62.5 & 36.5 & 12.7 & $\mathrm{x}$ & & & & & coarse-grained flint, tech traces \\
\hline & C & 9022 & 90182 & NA & 35.5 & 22.0 & 9.5 & & & & & & patina, heat treatment (?) \\
\hline & C & 9026 & 90175 & NA & 36.5 & 32.7 & 9.5 & $\mathrm{X}$ & & & & & patina, abrasion \\
\hline & C & 9029 & 90203 & NA & 88.0 & 53.2 & 19.0 & $x$ & & & & & coarse-grained flint, abrasion \\
\hline & $\mathrm{C}$ & 9038 & 90204 & NA & 50.0 & 41.5 & 18.2 & $x$ & & & & & lustrous \\
\hline & $\mathrm{C}$ & 1970 & 17940 & NA & 42.5 & 39.2 & 19.0 & $x$ & & & & & bifacial "flake core" \\
\hline & $E$ & 3135 & 30732 & NA & 69.0 & 47.8 & 14.0 & $\mathrm{x}$ & & & & & technological traces \\
\hline & $E$ & 3135 & 30737 & NA & 62.0 & 39.0 & 17.5 & & & & & & patina, technological traces \\
\hline & $E$ & 3193 & 31064 & NA & 73.0 & 61.0 & 24.0 & & & & & & caliche \\
\hline & E & 3193 & 31265 & NA & 40.0 & 45.0 & 15.0 & $\mathrm{x}$ & & & & & lateral snap \\
\hline & $E$ & 3234 & 31281 & NA & 59.0 & 46.0 & 17.5 & & & & & & heavy patina, worn edges \\
\hline & $\mathrm{K} 2$ & 5146 & 50633 & NA & 43.2 & 30.3 & 17.0 & $\mathrm{x}$ & & & & & patina, abrasion \\
\hline \multicolumn{14}{|c|}{$\begin{array}{l}\text { 2.B. Early Bronze Age (EBA) contexts } \\
\text { 2.B.1. Ventral type of COF }\end{array}$} \\
\hline & L & 6024 & 60119 & NA & 47.2 & 34.5 & 10.3 & $x$ & & & & & lustrous \\
\hline & L & 6071 & 60356 & NA & 63.5 & 38.0 & 17.5 & & & & & & coarse-grained flint \\
\hline & L & 6078 & 60253 & NA & 55.0 & 27.7 & 15.0 & $x$ & & & & & heavy patina, worn edges \\
\hline & L & 6079 & $60311-3$ & NA & 52.4 & 34.3 & 29.0 & $x$ & & & & & "flake-core" \\
\hline & $\mathrm{L}$ & 6081 & 60348 & NA & 47.5 & 40.0 & 11.0 & $\mathrm{x}$ & & & & & abrasion \\
\hline \multicolumn{14}{|c|}{ 3. PPNB contexts, Kombewa type blank } \\
\hline & $\mathrm{N} 2$ & 7322 & 73147 & NA & 16.8 & 19.7 & 2.5 & & & & & & abrasion \\
\hline
\end{tabular}




\section{Materials and methods}

A preliminary examination of a sample of 10 recycled artefacts was conducted in one of the archaeology labs at Tel Aviv University in August, 2014. Eight of these 10 are included in the larger microwear sample of 67 recycled lithic artefacts analyzed at Ohio State University (total microwear sample size is 69 recycled artefacts). They were examined to determine: (1) if they were utilized or hafted, (2) which edges were used, and (3) what materials were worked. "High-power" incident light methods developed by Semenov (1964) and Keeley (1980) were employed. Both "low-power" and "high-power" techniques provide information, but low-power methods do not allow discrimination between specific types of worked materials (Juel Jensen 1988; Longo and Skakun 2008; Yerkes and Kardulias 1993). In Tel Aviv, the artefacts were washed in soap and water, and examined with an incident light Nikon Optiphot metallurgical microscope at magnifications of 50x, 100x, 200x (see Keeley 1980; van Gijn 1990; and Yerkes et al. 2014 for more details on the methods of microwear analysis). The 10 artefacts in the preliminary analysis came from areas B, C, E, and L at the Ein-Zippori site (eight were from WR levels, 2 were from EBA levels). Nine of the 10 had visible microwear traces, although the use wear was not well-developed. It was decided to expand the sample, so a total of 67 artefacts were shipped to Ohio State University for further examination and microphotographic documentation. One COF examined in Tel Aviv (from Area B, Locus 3538, Bucket 14858, item \#2, Wadi Rabah), and a double-bulb (D.B.) lateral flake struck from a COF (from Area C, Locus 1996, Bucket 90071, also WR) were examined in Tel Aviv, but not shipped to Columbus. See the typology section (2.1) below for definitions of the types of blanks struck from COFs. In the microwear sample of 69 recycled artefacts, 56 were from WR levels, and 12 were from EBA contexts (Table 1). There also was one Kombewa type blank from a PPNB layer. At Ohio State University, the recycled artefacts were cleaned with detergent in a sonic cleaner and examined at magnifications between $62 \mathrm{x}$ and 375x with an Olympus BHM incident light microscope. Microphotographs were taken with a digital camera attachment at a magnification of $187.5 \mathrm{x}$. Microwear traces on the EinZippori artefacts were compared with use wear patterns on flaked stone tools in a reference collection of over 165 experimental tools made of a variety of different chert and flint types. The replica tools had been used for a variety of tasks including scraping, piercing, and cutting dry deer hide; scraping, sawing, and engraving bone and antler; cutting and scraping fresh hide and meat; scraping stone; and chopping, planning, whittling, sawing, and scraping wood. The functions of the Ein-Zippori artefacts were determined by matching microwear traces on their edges with use wear patterns on experimental replicas, or on published photomicrographs of wear traces on other types of experimental tools (e.g.,van Gijn 1990; 2010; Keeley 1980).

\subsection{Typology}

A typology for flake blanks and the recycled cores-on-flakes (COFs) from which the recycled blanks were detached was established during technological analysis of lithic artefacts from late Lower Paleolithic levels in Qesem Cave, Israel. Lemorini et al. (2015) and Parush et al. (2015) used "Cores-on-Flakes/Flaked Flakes (COF-FFs)" to refer to these parent flakes. A shorter designation (COFs) for cores-on-flakes will be used in this study. Descriptions of the types of blanks made from COFs have also been modified slightly for the Ein-Zippori material (see Parush et al. 2018).

As noted above, a "parent" flake from which smaller flakes were removed is classified as a core-on-flake (COF). Subtypes of COFs are defined by the location of the detached flakes (removals). Only one of 3 COF subtypes was included in the Ein-Zippori microwear sample. All 25 were COFs with flakes or blades removed from their ventral face (ventral removals). 
Of the 35 COFs with ventral removals, 20 (75\%) were from WR levels, 5 (25\%) were from EBA contexts. In the larger technological sample of recycled artefacts from Ein-Zippori, there were $301 \mathrm{COF}$, and $262(87 \%)$ were from WR contexts, while 39 (13\%) were from EBA levels. A total of 226 of the $301 \mathrm{COFs}(75 \%)$ were ventral removals, while $12 \%(n=37)$ were COFs with flakes removed from the ventral and dorsal faces (combined ventral and dorsal removals), and $13 \%(\mathrm{n}=38)$ were COFs with flakes removed from the dorsal face (dorsal removals). The last two subtypes of COFs were not included in the microwear sample. It is difficult to determine if COFs with dorsal removals are actual COFs. COFs with combined ventral and dorsal removals were also much less common than COFs with ventral removals (Parush et al. 2018).

Four types of flakes or blades were removed from the ventral face or lateral edges of COFs. Blanks removed from the dorsal face of COFs are difficult to identify and were not included in the sample (Figure 2). Two types of blanks were removed from the ventral face of COFs (and have two ventral faces, one on the COF and one on the detached flake): regular flakes, and double bulb Kombewa flakes that have two bulbs of percussion (one on the COF and one on their ventral face). Blades or flakes removed from the lateral edges of COFs also have two ventral faces, and include lateral flakes that retain one of the lateral edges of the parent COF, and double-bulb lateral flakes, which have bulbs on both ventral faces and also include part of the lateral edge of the COF. A fifth type of blank called the "Tabun snap" (Shifroni \& Ronen 2000) includes flakes struck from thick COFs.

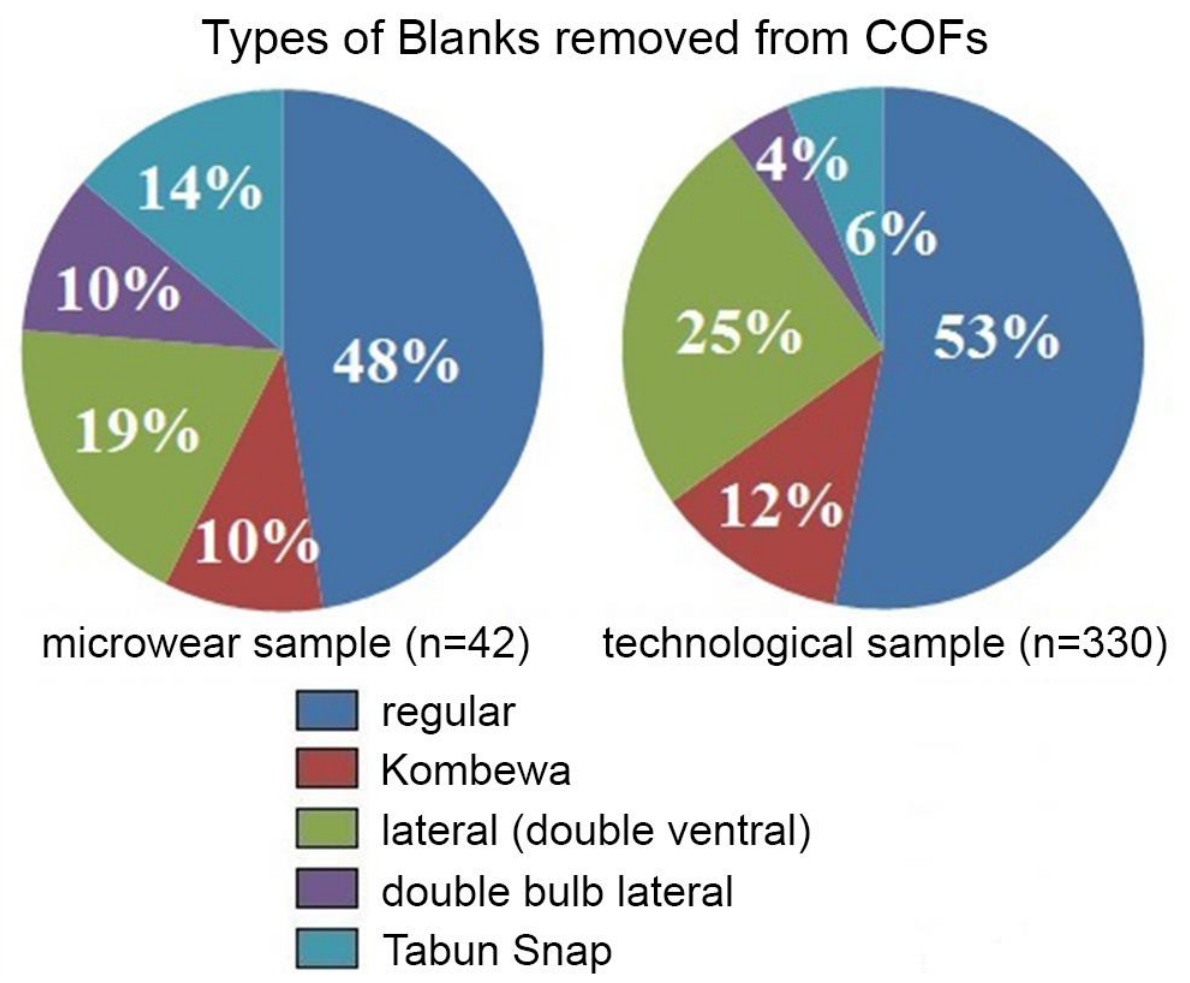

Figure 2. Percentage of types of blanks struck from COFs in the microwear sample $(n=42)$ left, and the larger technological sample $(\mathrm{n}=330)$. One WR blank examined for microwear (listed as varia on Table 1) could not be classifed, and the PPNB blank was not included. See Barkai et al. (2010); Lemorini et al. (2014); and Parush et al. 2018 for details on typology.

In the microwear sample, 36 of the 44 blanks (82\%) were from WR contexts and $7(16 \%)$ were from EBA levels (one Kombewa blank, 2\%, was from a PPNB layer). In the larger technological sample of 330 flakes or blades, $84 \%$ came from WR levels and $16 \%$ were from EBA contexts. Nearly half $(48 \%, \mathrm{n}=20)$ of the blanks in the microwear sample were regular 
flakes, and these were also the most common type in the larger technological sample (53\%, $\mathrm{n}=176$ ), but examples of all five types were included in the microwear study (Table 1, Figure 2). However, the percentage of double-bulb lateral and Tabun snap flakes were higher in the microwear sample (10\% and $14 \%$ vs. $4 \%$ and $6 \%$ ) and the percentage of lateral (double ventral) flakes was lower (19\% vs. 25\%). See Barkai et al. (2010), Lemorini et al. (2015), and Parush et al. (2015; 2018) for more details on the typology and discussion of the technological details of recycled flake production.

\section{Results of the microwear analysis}

\subsection{Cores-on-Flakes (COFs)}

As noted above, cores-on-flakes (COFs) may have microwear traces that formed during their initial use before they were discarded and later recycled. The focus of this study is on the flake blanks struck from them. However, microwear was visible on 3 cores-on-flakes (12\% of 25 examined, Table 1). All three are from WR layers (15\% of $20 \mathrm{WR}$ COFs). None of the 5 EBA COFs had visible microwear. This is comparable to results of microwear analysis of Lower Paleolithic recycled flakes from Qesem Cave, Israel, where 15\% of examined COFs were utilized (Lemorini et al. 2014). Lemorini suggested that parent flakes were not the desired product in recycled flake production. This seems to have also been the case at EinZippori.

The 3 utilized COFs from Ein-Zippori included one with a lateral snap at its distal end. A lateral snap, or bending fracture, is a common type of flint knapping production failure produced by force exerted perpendicular to the dorsal and ventral faces of the core-on-flake (Johnson 1981:47; Purdy 1975:134). Lateral snaps resemble step terminations (Andrefsky 1998). The COF with the lateral snap termination was from Area B, Locus 3538, Bucket 14858 (item\#1). This steep edge (edge angle, E.A. $=60^{\circ}$ ) was probably used to scrape meat or fresh hide off of bone (light butchering). There was very little use wear, but bone seems to have been nicked with the tool producing some small patches of bone microwear polish. One of the lateral edges of this COF was also used for cutting meat or fresh hide (Figure 3A, a, b, c). The micowear was not well developed, and there was very little edge damage. Another $\mathrm{COF}$ with ventral flake removals had a small patch of dry hide and stone-on-stone microwear on one of its steep lateral edges (E.A. $=70^{\circ}$ ). It seems to have been used as an expedient hide and stone scraping tool (Figure 3B, d). The third utilized COF was examined in Tel Aviv (not illustrated). It had a few meat or fresh hide and bone traces along one of its edges. The orientation of the microwear suggested cutting and scraping. Possible prehension traces were also recorded (Table 1). Like the COF with the lateral snap (above), this COF from the same Area (B), Locus (3538), and Bucket (14858, it is item \#2) seems to have been used as an expedient butchering tool. 

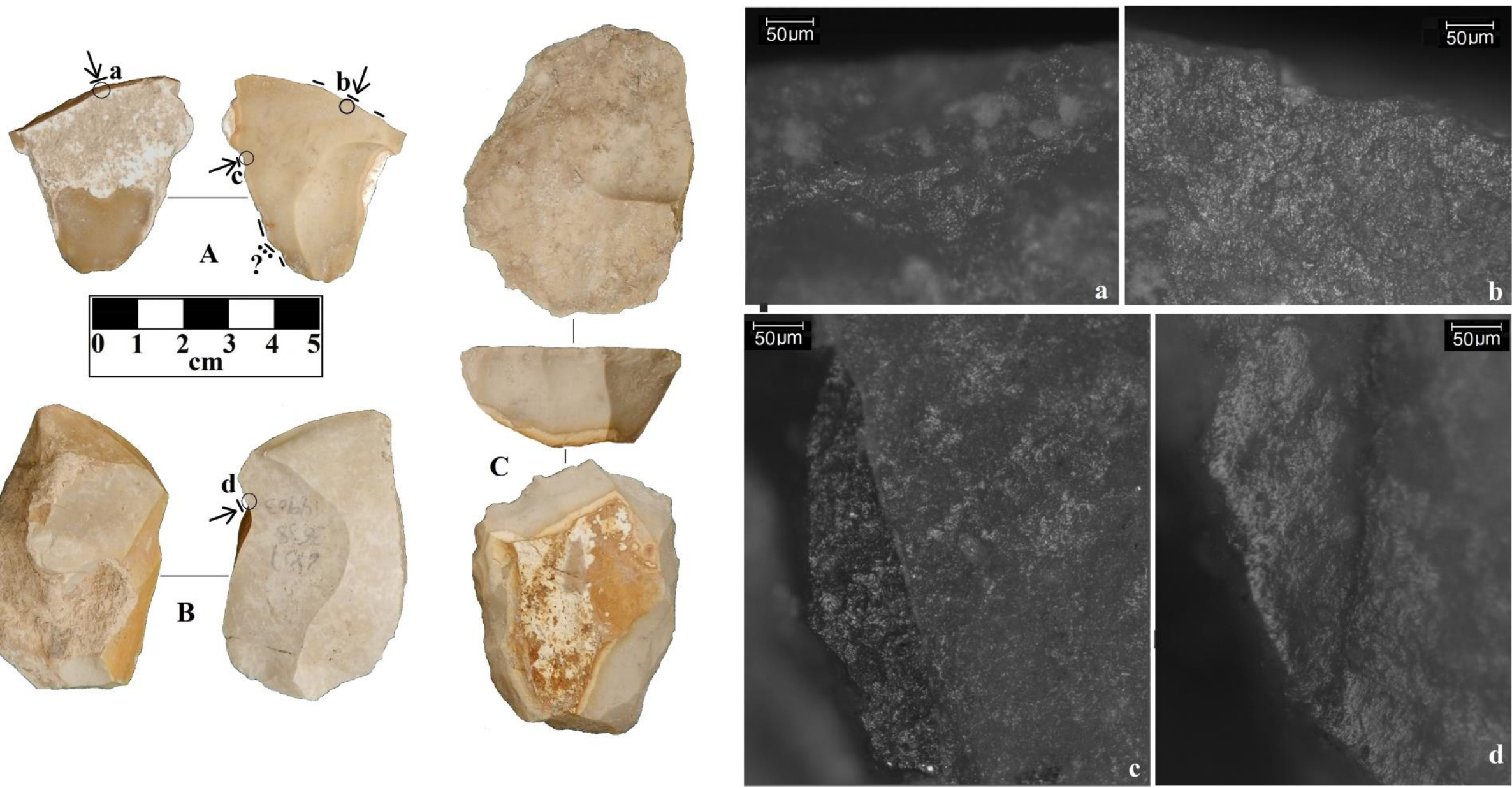

Figure 3. Dorsal (left or bottom), ventral (right or top), and lateral (middle) faces of cores-on-flakes (COFs) from Wadi Rabah layers at Ein-Zippori. White chalky cortex and caliche cover most of their dorsal faces. White lines show the extent of the usewear traces, arrows show orientation of the microwear polishes and striations, line with dots shows possible prehension traces. Circles show locations of photomicrographs a, b, c, and d. A: COF with lateral snap from Area B, Locus 3538, Bucket 14858, item\#1. B: Lustrous COF from Area B, Locus 3538, Bucket 14903. C: COF from Area C, Locus 9025, Bucket 90157 with several flake removals around perimeter, but no visible use wear. a: Bright bone and rough hide or meat polish at medial distal edge (dorsal) of A. b: More extensive rough hide or meat polish on right distal edge (ventral) of A. c: Streaks of bright bone or stone traces and rough hide or meat polish in small notch on distal left lateral edge (ventral) of $\mathbf{A}$. Possible prehension traces were noted on the proximal portion of same edge. d: Edge-rounding, striations, hide polish and stone-on-stone wear on distal left lateral edge (ventral) of B. photomicrographs are at 187.5x, scales are 50 microns. 


\subsection{Blanks struck from core-on-flakes (COFs)}

Of the 44 blanks removed from COFs in the Ein-Zippori entire microwear sample, 19, or $43 \%$ were utilized (Table 1, Figure 4). Only 2 of the 19 (10\%) were from EBA levels, one of these was used for light butchering and the other to cut, scrape, and whittle bone or wood. Of the 17 utilized WR blanks (90\% of the total), 7 (41\%) seem to have been used for light butchering (cutting meat and fresh hide and scraping meat off of bones). Four (24\%) were used as wood-working scrapers, gravers, and knives. Three utilized WR blanks were used to cut, scrape, and whittle bone or wood (18\%). Two were used to cut and scrape meat and soft wood (12\%). One blank, from the same Area (E), Locus (3135), and Bucket (30816), as a flake used for light butchering, only had weakly-developed "generic" microwear traces $(5 \%)$ that may have formed when it was used to cut or scrape meat, but it was not certain that it was used for butchering (Table 1, Figure 4).

\section{Microwear on 19 utilized blanks removed from COFs Ein Zipporo site, Isreal}

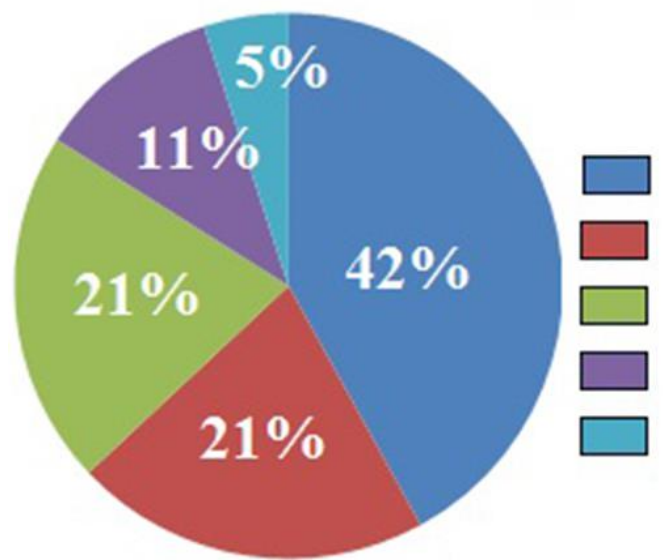

light butchering

working wood

cut, scrape, or whittle bone or wood

cut or scrape meat and soft wood

generic weak microwear

Figure 4. Frequencies of different patterns of microwear on 19 utilized recyled flake blanks struck from coreson-flakes (COFs) in the sample from the Ein-Zippori site. Microwear on most (42\%) is from light butchering (cutting fresh hide and meat and scraping meat off of bones). Four (21\%) were used for wood-working, 4 others $(21 \%)$ were used to cut, scrape, and whittle bone or wood, and $2(11 \%)$ were used to cut or scrape meat and soft wood. One had "generic" microwear traces that could not be associated with a specific task.

All 19 utilized blanks had edges with rather sharp edge-angles (E.A.) of $20^{\circ}-45^{\circ}$, but most of the sharper edges were used for cutting, while the steeper edges were used for scraping or whittling. None of the utilized blanks had visible hafting traces (Figure 4). The single flake that could not be classified (listed as varia on Table 1) was not utilized.

Microwear traces were visble on all five types of blanks struck from COFs (Table 1). Each type of blank was used for several different tasks. Regular flakes were the most common form, and 9 of the 20 regular flakes in the Ein-Zippori sample (45\%) were utilized. Eight were from WR levels, one was from an EBA context (Table 1). Not all of the utilized Regular flakes are illustrated, but 5 (Figures $5 \mathrm{~B}, \mathrm{C} \& \mathrm{D} ; 6 \mathrm{~A}$ ) were used for light butchering (56\%), 2 were used to cut meat and work soft wood (22\%, Figure 7A \& B, Table 1). Two others, one from an EBA (Figure $8 \mathrm{~A}$ ) and one from a WR level (Figure $8 \mathrm{~B}$ ), were used to cut and scrape (or whittle) bone or wood (22\%). 

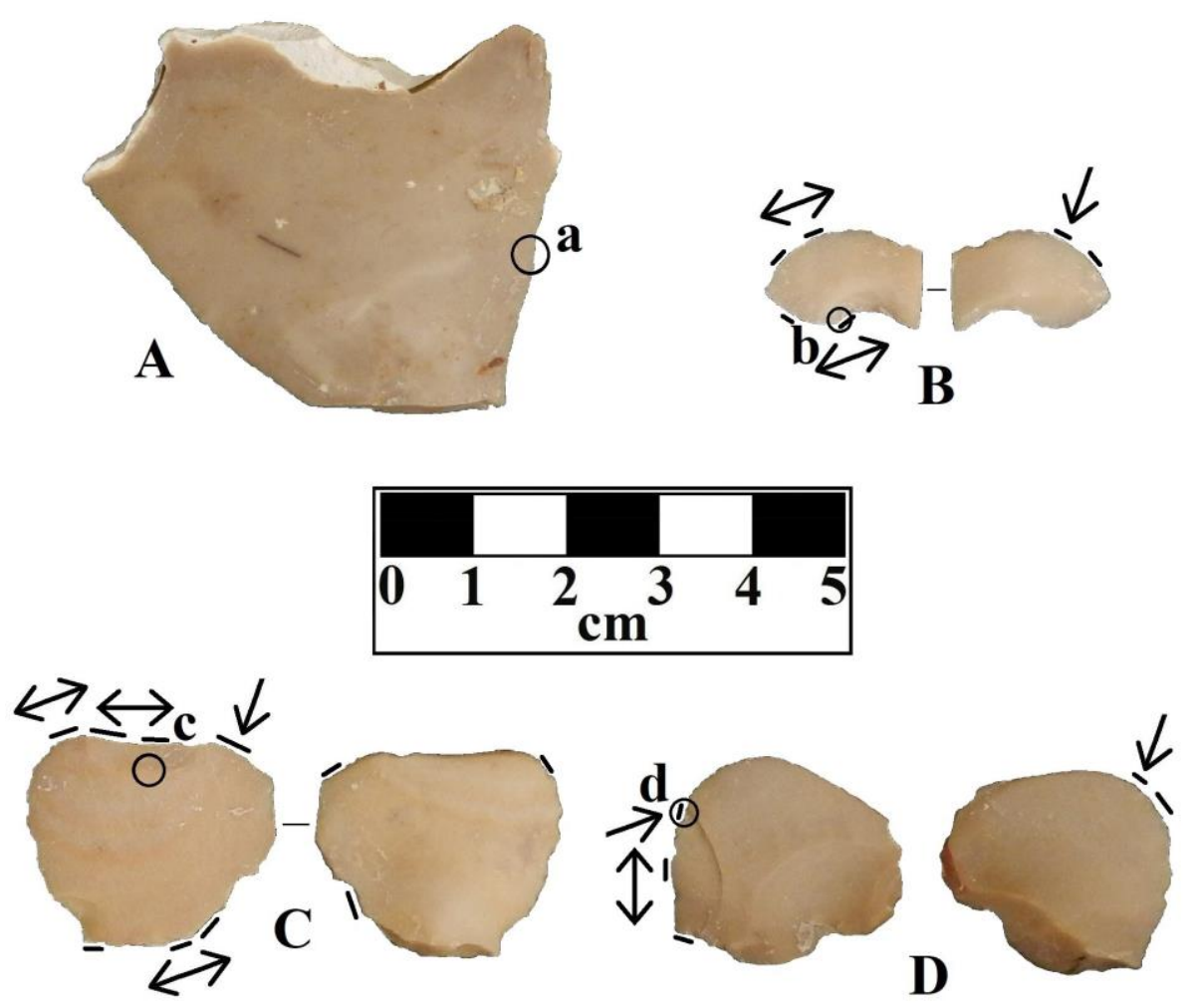

$\mathbf{D}$ end at top. White lines: extent of microwear traces, arrows: orientation of polishes and striations, white circles: locations of photomicrographs $\mathbf{a}$, b, c, \& $\mathbf{d}$. A: Area K2, Locus 5146, Bucket 50662. Cortex covers most of the distal end. No visible microwear. B: Area E, Locus 3135, Bucket 30816, item \#1. C: Area C, Locus 9026, Bucket 90127. D: Area B, Locus 3538, Bucket 14858. a: "natural luster" on unused right lateral edge of A. b: rough hide or meat polish on left proximal edge (dorsal) on B from expedient meat or fresh hide cutting and scraping. c: bright bone, rough hide or meat polish, and striations parallel to the distal edge (dorsal) along flake scar on $\mathbf{C}$ from expedient meat or hide cutting and scraping where bones were "nicked" and grit may have been dragged across the flake forming the striae. $\mathbf{d}$ : bright bone and rough hide or meat polish on left lateral edge (dorsal) of $\mathbf{D}$ that was probably from scraping meat off of bone. This part of the lateral edge had a steeper edge-angle $\left(45^{\circ}\right)$ than the other utilized part of the same edge. The microwear on the medial left lateral edge (dorsal) of $\mathbf{D}$, with an E.A. of $30^{\circ}$, was used to cut meat or fresh hide. Utilized edged of $\mathbf{B}$ and $\mathbf{C}$ also had sharp edgeangles $\left(20-25^{\circ}\right)$. Microwear traces are not well-developed on utilized blanks, but could be distingished from the "natural luster" on A. All photomicrographs are $187.5 x$, with scales of 50 microns. 


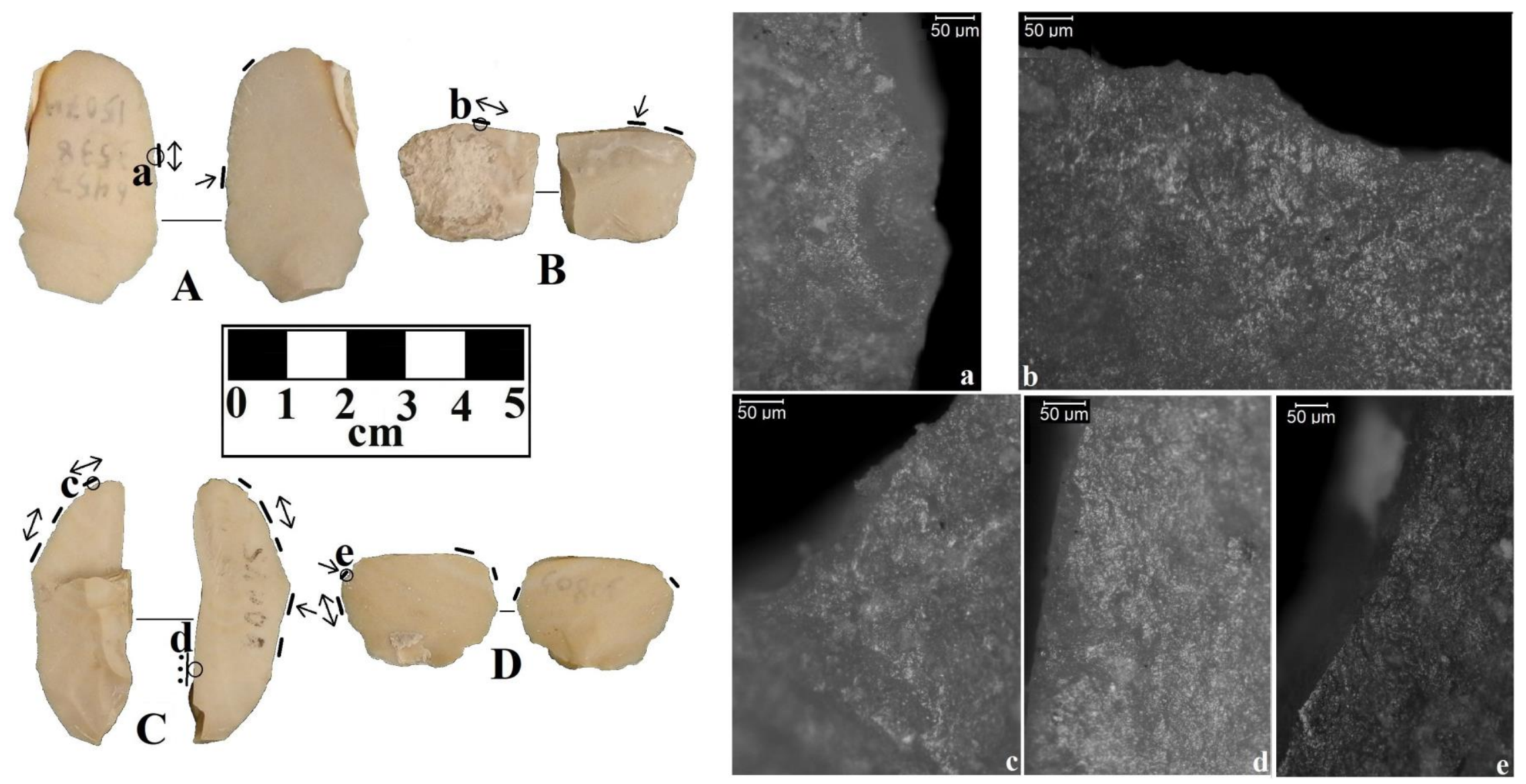

Figure 6. Dorsal (left) and ventral (right) faces of regular $(\mathbf{A})$, Kombewa $(\mathbf{B})$, lateral $(\mathbf{D})$, and Tabun snap $(\mathbf{C})$ blank types from Wadi Rabah layers (A, C, D) and EBA layers (B) at Ein-Zippori. Proximal (bulbar) end at bottom, distal end at top. White lines: extent of microwear traces, arrows: orientation of polishes and striations, white circles: locations of photomicrographs a, b, c, d \& e. A: Area B, Locus 3538, Bucket 15074 (WR). Chalky cortex on part of lateral edge. B: Area B, Locus 1321 , Bucket 13266. Cortex and caliche on dorsal face. C: Area C, Locus 1996, Bucket 90045. D: Area E, Locus 3135, Bucket 30805, item \#1. Caliche on dorsal face. a: bright bone and rough hide or meat polish on right lateral edge (dorsal) sharp edge-angle ( $\left.20^{\circ}\right)$ on $\mathbf{A}$ from cutting and scraping of meat, fresh hide or both. $\mathbf{b}$ : rough hide or meat polish on distal edge (dorsal) of $\mathbf{B}$ with steeper edge angle (45 ) from expedient meat or fresh hide cutting and scraping. c: bright bone or stone and rough hide or meat polish on thin distal left lateral edge (E.A. $25^{\circ}$ ) above Tabun snap on C. d: possible prehension traces on proximal left lateral edge (ventral) of C. Thin edge was used for cutting meat or hide, thicker edge was used for scraping meat or fresh hide, and possibly bone. e: bright bone or stone and rough hide or meat polish on thin (E.A. 20 ) distal left lateral edge (dorsal) of D also used for expedient meat or hide cutting and scraping where bones may have been "nicked." Microwear was not very well-developed on any blanks. All photomicrographs $187.5 \mathrm{x}$, scales are 50 microns. 

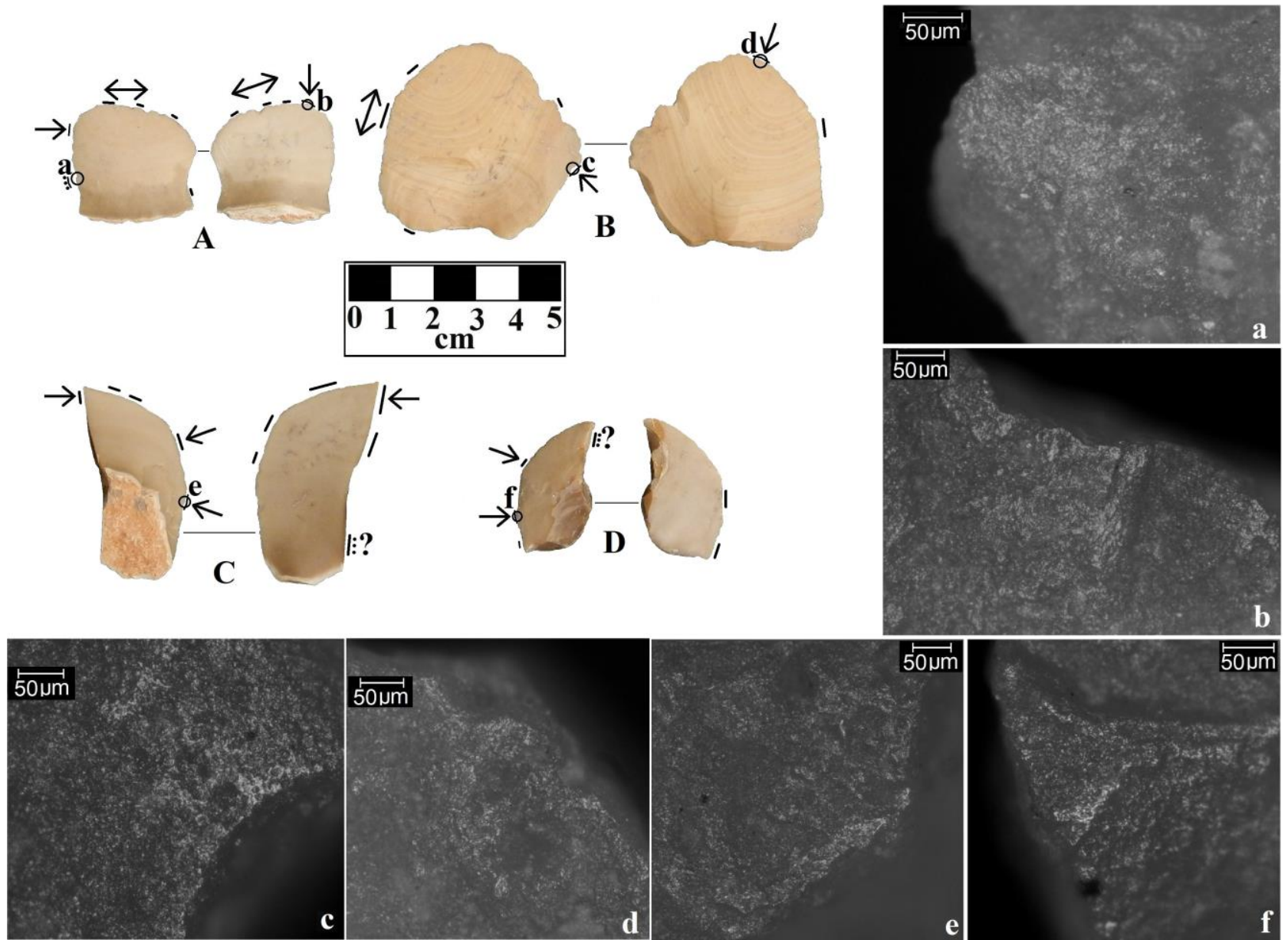

Figure 7. Dorsal (left) and ventral (right) faces of regular (A, B), Tabun snap (C) and Kombewa (D) type blanks from WR layers at Ein-Zippori used to cut or scrape meat or soft wood $(\mathbf{A} \& \mathbf{B})$ or work wood $(\mathbf{C} \& \mathbf{D})$. White lines show the extent of the usewear traces, arrows show orientation of the microwear polishes and striations, line with dots shows possible prehension traces. White circles show locations of photomicrographs a, b, c, d, e, and f. A: Area C, Locus 1970, Bucket 17722. Cortext on proximal end. B: Area C, Locus 1996, Bucket 90038. C: Area C, Locus 1996, Bucket 90071. Cortex covers one third of the dorsal face. D: Area C, Locus 1999, Bucket 17935, lustrous. a: Prehension traces on proximal left lateral edge (dorsal) of A. b: Bright wood polish and duller meat polish on distal edge (ventral) of A. Edge-Angle is $25^{\circ}$. c: Bright wood polish on right lateral edge (dorsal) of B. d: Rough meat polish on distal edge (ventral) of $\mathbf{B}$. At $\mathbf{c}$ and d, E.A. is $20^{\circ}$. e: Bright wood polish normal to right lateral edge (dorsal) of C. E.A. is $45^{\circ}$. f: Bright wood polish and striae on left lateral edge (dorsal) of D. E.A. $45^{\circ}$. Possible prehension traces were also visible on C and D. All photomicrographs $187.5 \mathrm{x}$, with scales that are 50 microns. 


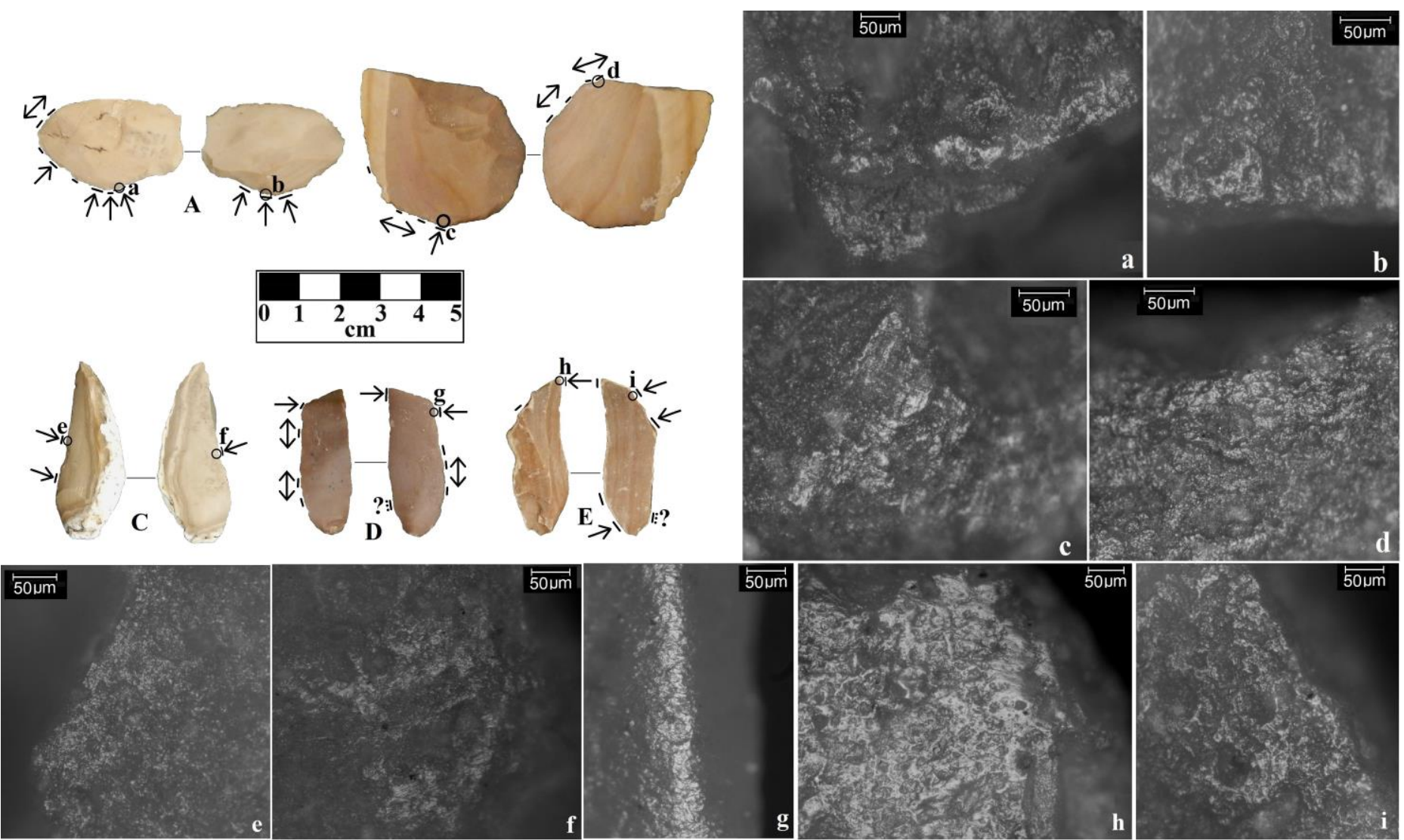

Figure 8. Dorsal (left) and ventral (right) faces of Regular (A, B), Lateral (E), and Double-bulb Lateral (C, D) type blanks from Ein-Zippori used to cut, scrape or whittle meat, bone, and wood (A-D), and work wood (E). A is from an EBA layer, the others are from WR contexts. White lines: extent of microwear, arrows: orientation of polishes and striations, white circles: locations of photomicrographs $\mathbf{a}, \mathbf{b}, \mathbf{c}, \mathbf{d}, \mathbf{e}, \mathbf{f}, \mathbf{g} \mathbf{h} \& \mathbf{i}$. A: Area B, Locus 1501, Bucket 13923. B: Area E, Locus 3135, Bucket 30737. C: Area C, Locus 9022, Bucket 90134. Cortex covers base and lateral edge. D: Area N2, Locus 7319, Bucket 73141, lustrous. E: Area E, Locus 3234, Bucket 31298, worn. a: bright domed bone or wood polish with short striae normal to the proximal edge (dorsal) of $\mathbf{A}$. b: bright domed bone or wood polish, striae, and duller meat polish on ventral face of proximal edge of $\mathbf{A}$. Edge-angle of proximal edge is $40^{\circ}$, distal edge is $20^{\circ}$. c: bright bone or wood polish with striae normal and parallel to the proximal edge (dorsal) of $\mathbf{B}$. d: rough "greasy" meat or fresh hide polish parallel to left distal edge (ventral) of B. Proximal E.A. is $40^{\circ}$, disal E.A. is $30^{\circ}$. e: bright bone or wood and rough meat polish normal to left lateral edge (dorsal) of C. f: bright domed bone or wood polish and short striae on the ventral face of same edge of C. E.A. is $45^{\circ}$. g: bright domed bone or wood polish and striae normal to distal right lateral edge (ventral, E.A. $45^{\circ}$ ) of D. Similar microwear visible on opposite distal lateral edge. Meat or fresh hide polish parallel to the left lateral edge (dorsal). h: bright domed soft wood polish and striae normal to the distal right lateral edge (dorsal) of $\mathbf{E}$ (E.A. $50^{\circ}$ ). i: less-developed wood polish normal to right lateral edge (ventral) of E. Possible prehension traces were visible on $\mathbf{D}$ and $\mathbf{E}$. Photomicrographs $187.5 \mathrm{x}$, with scales of 50 microns. 
Wear traces were also identified on 2 of the 4 Kombewa type flakes (50\%). One from an EBA level was used for light butchering (Figure 6 B). Microwear on the other (WR) blank was not well-developed. Apparently it was used for scraping or whittling soft wood (Figure 7 D). Four of 8 lateral flakes were utilized (50\%), all from WR layers. One was used for light butchering (Figure $6 \mathrm{D}$ ). Two were used to cut, scrape and engrave wood (Figure $8 \mathrm{E}$ ). The fourth showed only generic weak microwear traces (possibly meat). Two of 4 double-bulb (D.B.) lateral flakes also had microwear (50\%). Both were used to cut, scrape, and whittle bone or wood (Figure $8 \mathrm{C} \& \mathrm{D}$ ).

Of the six WR Tabun snap flakes in the samples, two were utilized (33\%). One was used for cutting and scraping meat or fresh hide and bone (or light butchering). This use wear was visible on a utilized edge above the Tabun snap (Figure $6 \mathrm{C} \& \mathrm{c}$ ). The use wear on the other was not well-developed. Apparently it was used for scraping or whittling soft wood (Figure 7 C).

Wear that may have been cause by prehension (holding the flakes tightly when they were being used) was recorded on 6 flakes: 3 regular flakes, 2 double-bulb lateral, and one Tabun snap. It is likely that all of the utilized flakes were held in the hand when used, since no clear hafting traces were noted on any of them (see Rots 2010 for details on hafting and prehension microwear). Examples of prehension traces are shown on Figures $6 \mathrm{~d} \& 7$ a.

One Kombewa flake with "natural luster" on its edges is also shown (Figure 5 A \& a). Many of the COFs and blanks in the Ein-Zippori sample had lustrous surfaces, and at times it was difficult to recognize the microwear traces. However, even though the utilized recycled COFs and blanks had only been used for a short time, distinctive polish and striation patterns similar to those on experimental stone tools were visible, and it was possible to interprete their functions. For example, Figure 5, B, C, and D are small regular flakes with sharp edges that have rough hide or meat microwear polish on their edges (Figure $5 \mathrm{~b}$ ), or hide or meat and brighter bone polish (Figure $5 \mathrm{c} \& \mathrm{~d}$ ). These 3 small sharp-edged regular flakes were probably held in the hand and used as expedient butchering tools.

On Figure 6 there are four different types of blanks that were all used as expedient butchering tools, regular (Figure $6 \mathrm{~A})$, Kombewa (6 B), Tabun snap (6 C), and lateral (6 D). The variation in these blank types that were all used for the same task illustrates the expedient use of small recycled flakes. Any flake with thin razor-sharp edges struck from a parent COF was selected for meat and hide cutting and for scraping meat off of bones. No specific type of blank was produced only to be used for the light butchering.

On Figure 8, two regular flakes (A and B) that were used to cut, scrape, or whittle bone, wood, or both are illustrated. Some of the edge-angles $\left(30^{\circ}\right.$ and $\left.40^{\circ}\right)$ on these regular flake blanks are steeper than the razor-edged blanks shown in Figure 6. They seem to have been more versatile flake tools used for bone or wood scraping and whittling. A wedge-shaped double-bulb lateral flake blank (Figure $8 \mathrm{C}$ ) was also used for bone or wood scraping and whittling. The distal end of this blank could have been used as a graver to cut grooves in wood, bone, or antler objects, but there were no visible wear traces on that part of the blank. However, bone or wood microwear (Figure $8 \mathrm{~g} \& \mathrm{~h}$ ) was visible on graver edges of another double-bulb lateral flake (Figure $8 \mathrm{D}$ ), and on a lateral flake (Figure $8 \mathrm{E}$ ). Possible prehension microwear on one lateral edge of the double-bulb lateral flake $(7 \mathrm{D})$ suggested that it had been held in the hand when it was used. The lateral flake (7 E) was worn, but it also seems to have been used to scrape soft wood or bone (Figure 8 i). Possible prehension traces were also visible on this flake.

On Figure 7, two regular flakes A and B are shown with weakly-developed microwear traces that suggest that they may have been used to cut and scrape both meat and soft wood (Figure $7 \mathrm{~b}, \mathrm{c} \& \mathrm{~d}$ ). Prehension traces near the base of one of the regular flakes are also shown (Figure 7 a). Both a Tabun snap flake (Figure 7 C) and a Kombewa flake (Figure 7 D) also 
had possible prehension traces, and weakly-developed bright wood polish (Figure 7 e \& f). The Tabun snap blank (Figure 7 C) had a "graver-like" tip, with some weak possible wood or bone microwear. The possible prehension traces on the Kombewa flake (Figure 7 D) were near its "graver-like" distal end. While the microwear traces are not well-developed, these two blanks with pointed ends (Figure $7 \mathrm{C} \& \mathrm{D}$ ) look like they could have been used as gravers, but instead were used to scrape or whittle wood.

\section{Conclusions}

Microwear traces on many of the 19 utilized blanks struck from recycled COFs found at Ein-Zippori were quite similar to the wear traces that Lemorini et al. (2015) observed on recycled Paleolithic artefacts from Qesem Cave. The micowear on the blanks struck from COFs is from new tasks that were performed with them. In the microwear sample of 134 recycled blanks from the late Lower Paleolithic contexts at Qesem Cave, most regular flake blanks had been used for cutting meat while many lateral flakes were used to cut plants (Lemorini et al. 2015). The small thin regular flakes were also the most common type in the microwear sample from Ein-Zippori, and while 56\% of them were used for light butchering, they were also used for bone-working (22\%) and wood-working (22\%). The other four blank types that were utilized, lateral flakes, Kombewa flakes, double-bulb lateral flakes, and Tabun snap flakes, also were used for light butchering, meat cutting, and bone and wood working. At Ein-Zippori, there does not seem to be a strong correspondence between the form of the blanks struck from COFs and their functions.

"Older" flakes from earlier activities and occupation episodes were recycled during the Paleolithic at Qesem Cave, and during the Late Pottery Neolithic and Early Bronze Age periods at Ein-Zippori. The products of recycling were expedient flake tools that were made and used in an ad hoc fashion. However, the way that the blanks were used by the WR and EBA settlers at Ein-Zippori was a little different. The majority of the recycled blanks examined in this study came from WR levels (82\%), and $47 \%$ of the WR blanks were utilized, while only $28 \%$ of the EBA blanks in the sample had been used, so the picture of recycling during the Wadi Rabah phases is clearer. Nonetheless, both WR and EBA inhabitants of EinZippori did not produce specific types of small blanks from recycled COFs that they used for specific tasks like mobile Paleolithic foragers had done at a much earlier time. They made and used several new types stone tools in their farming, herding, and craft activities. Their use of recycled flakes seems to have been for light butchering and wood and bone working when they did not have their flaked stone or metal knives and scrapers with them. They used the discarded flakes they found lying around as cores and produced sharp-edged flakes to cut meat or to scrape or whittle bone or wood. These activities seem to have occurred at many locations across the settlement and do not seem to be associated with specific butchering or crafting areas.

\section{References}

Agam, A., Walzer, N., Schechter, H., Zutovski, K., Milevski, I., Getzov, N., Gopher, A. \& Barkai, R. 2016, Organized waste disposal in the Pottery Neolithic: A bifacial workshop refuse pit at Ein-Zippori, Israel. Journal of Field Archaeology, 41: 713-730. doi:10.1080/00934690.2016.1240598

Andrefsky, W., Jr. 1998. Lithics: Macroscopic approaches to analysis. Cambridge University Press, Cambridge, 258 p. 
Barkai, R., Lemorini, C., \& Gopher, A. 2010, Paleolithic cutlery 400,000-200,000 years ago; tiny meat-cutting tools from Qesem Cave, Israel. Antiquity, Project Gallery, 84(325): online. URL: https://www.antiquity.ac.uk/projgall/barkai325/

van Gijn, A. L. 1990. The Wear and Tear of Flint: Principles of Microwear Analysis Applied to Dutch Neolithic Assemblages. Analecta Praehistorica Leidensia Vol. 22, University of Leiden, Leiden, $182 \mathrm{p}$.

van Gijn, A. 2010, Flint in Focus: Lithic Biographies in the Neolithic and Bronze Age. Sidestone Press, Leiden, 289 p.

Johnson, J. K., 1981, Lithic Procurement and Utilization Trajectories: Analysis, Yellow Creek Nuclear Power Plant Site, Tishomingo County, Mississippi, Vol. 2. Archaeological Papers, Center for Archaeological Research 1, University of Mississippi, and TVA Publications in Anthropology Vol. 28, University of Mississippi, Mississippi, 347 p.

Juel Jensen, H. 1988, Functional Analysis of Prehistoric Flint Tools by High-Power Microscopy: A Review of West European Research. Journal of World Prehistory, 2: 53-88. doi:10.1007/BF00975122

Keeley, L. H. 1980, Experimental Determination of Stone Tool Uses: A Microwear Analysis. University of Chicago Press, Chicago, $226 \mathrm{p}$. URL: http://press.uchicago.edu/ucp/books/book/chicago/E/bo3615551.html

Lemorini, C., Venditti, F., Assaf, E., Parush, Y., Barkai, R., \& Gopher, A. 2014, The function of recycled lithic items at late Lower Paleolithic Qesem Cave, Israel: An overview of the use-wear data. Quaternary International, 361: 103-112. doi:10.1016/j.quaint.2014.07.032

Longo, L., \& Skakun, N., (Eds.), 2008, "Prehistoric Technology" 40 Years Later: Functional Studies and the Russian Legacy. Oxford, BAR International Series Vol. S1783, Oxford: Oxbow, Oxford, $559 \mathrm{p}$.

Parush, Y., Assaf, E., Slon V., Gopher, A. \& Barkai, R. 2015, Looking for Sharp Edges: Modes of Flint Recycling at Middle Pleistocene Qesem Cave, Israel. Quaternary international, 361: 61-87. doi:10.1016/j.quaint.2014.07.057

Parush, Y., Yerkes, R., Efrati, B., Barkai, R., \& Gopher, A. 2018, Flint recycling in the Neolithic and Early Bronze Age: Evidence for small flakes production by means of recycling at Ein-Zippori, Israel. Journal of Lithic Studies, 5(1): 32 p. CURRENT ISSUE doi: $10.2218 / \mathrm{jls} .2666$

Purdy, B. A., 1975, Fractures for the archaeologists. In: Lithic Technology: Making and Using Stone Tools (Swanson, E., Ed.), Aldine, Chicago: p. 133-141.

Rots, V. 2010, Prehension and Hafting Traces on Flint Tools. Leuven University Press, Leuven, $298 \mathrm{p}$.

Semenov, S.A. 1964, Prehistoric Technology. Barnes and Noble, New York, 211 p.

Shifroni, A. \& Ronen, A. 2000, The "Tabun Snap" fron the Yabrudian/Acheulean Interface at Tabun. Praehistoria (International Prehistory Journal of the University of Miskolc, Hungary), 1: 109-116. 
Vaquero, M., Alonso, S., García-Catalán, S., García-Hernández, A., Gómez de Soler, B., Rettig, D. \& Soto, M. 2012. Temporal Nature and Recycling of Upper Paleolithic Artifacts: the Burned Tools from the Molídel Salt Site (Vimbodíi Poblet, Northeastern Spain). Journal of Archaeological Science, 39: 2785-2796. doi:10.1016/j.jas.2012.04.024

Yerkes, R. W., Galili, E., \& Barkai, R. 2014, Activities at final Pre-Pottery Neolithic (PPNC) Fishing Village revealed through Microwear analysis of bifacial flint tools from the submerged Atlit-Yam site, Israel. Journal of Archaeological Science, 48: 120-128. doi:10.1016/j.jas.2013.09.022

Yerkes, R.W., \& Kardulias, P.N. 1993. Recent Developments in the Analysis of Lithic Artifacts. Journal of Archaeological Research, 1: 89-119. doi:10.1007/BF01326933

Yerkes, R.W., \& Koldehoff, B.H. 2018. New tools, new human niches: The significance of the Dalton adze and the origin of heavy-duty woodworking in the Middle Mississippi Valley of North America. Journal of Anthropological Archaeology, 50: 69-84. doi:10.1016/j.jaa.2018.03.002 